\title{
Convictions versus Conviction Rates: The Prosecutor's Choice
}

\author{
December 31, 2008
}

Eric Rasmusen, Manu Raghav, and Mark Ramseyer

\begin{abstract}
It is natural to suppose that a prosecutor's conviction rate- the ratio of convictions to cases prosecuted - is a sign of his competence. Prosecutors, however, choose which cases to prosecute. If they prosecute only the strongest cases, they will have high conviction rates. Any system which pays attention to conviction rates, as opposed to the number of convictions, is liable to abuse. As a prosecutor's budget increases, he allocates it between prosecuting more cases and putting more effort into existing cases. Either can be socially desirable, depending on particular circumstances. We model the tradeoffs theoretically in two models, one of a benevolent social planner and one of a prosecutor who values not just the number of convictions but the conviction rate and unrelated personal goals. We apply the model to U.S. data drawn from county-level crime statistics and a survey of all state prosecutors by district. Conviction rates do have a small negative correlation with prosecutorial budgets, but conditioning on other variables in regression analysis, higher budgets are associated both with more prosecutions and higher conviction rates.
\end{abstract}

Eric Rasmusen: Indiana University, Kelley School of Business, BU 438, 1309 E. 10th Street, Bloomington, Indiana 47405-1701. Office: (812) 855-9219. Fax: 812-855-3354. Erasmuse@indiana.edu, http: //www.rasmusen.org.

Manu Raghav: DePauw University, Department of Economics and Management, 7 E. Larabee St, Greencastle, Indiana 46135. Manuraghav@depauw.edu.

Mark Ramseyer: Harvard Law School, Cambridge, Massachusetts 02138. Ramseyer@law.harvard.edu.

We thank Michael Baye, Matthew Gens, Louis Kaplow, Reed Smith, and participants in talks at the 2005 Midwest Law and Economics Association Conference, IUPUI, Emory University, Harvard Law School, and Indiana University for helpful comments. 


\section{Introduction}

Attorney Thomas Broderick Jr. will formally announce Tuesday that he is a candidate for the Democratic nomination for Madison County prosecutor. He was chief deputy for Prosecutor William F. Lawler Jr. for more than seven years, claiming a 98 percent personal conviction rate on cases ranging from drugs to murder. ${ }^{1}$

So reads a typical press release in an election for county prosecutor. The prosecutor's role is one of the most important in criminal justice, yet one of the most neglected by scholarship. Standing between the criminal and the police on the one hand and the courts and prisons on the other, the prosecutor has two jobs. One, as candidate Broderick stresses, is to convince the court to convict. The other is to decide whom to prosecute.

Other things equal, it is good to have a prosecutor who wins cases. But other things are not equal. A prosecutor might choose to prosecute innocent enemies. He might choose to prosecute very few cases. Were he to spend an entire year prosecuting one case, he could easily obtain not a 98 percent conviction rate, but 100 percent. A high win rate might actually tell us the prosecutor is slack, not tough. As a former Securities and Exchange Commission examiner said after the SEC failed to respond to explicit warnings about the Madoff Ponzi scheme:

During my time at the SEC, I heard the excuses about why cases that we, the examination staff, uncovered failed to warrant actions by the enforcement staff. Too small - best wishes to the small investors involved. Too complicated - derivatives would fall under this category. Too politically connected - don't want to rock the boat. In many ways, the Madoff fraud shares the same excuses for not being uncovered as the unmitigated disasters that were Fannie Mae and Freddie Mac, AIG and the subprime mortgage lenders.

Part of the problem is that enforcement likes to bat 1.000, because of the way the system works, meaning they like to bring only cases they will win. I recall that anything less than that resulted in warning letters or no actions whatsoever. ${ }^{2}$

In this article, we focus on the problem of case selection: whether to allocate resources broadly over many cases or intensively to a few cases. Consider the contrast between the United States and Japan. Conviction rates are high in both countries, but higher in Japan. American state prosecutors win 85 percent of their felony cases and 90 percent of their misdemeanors. Federal prosecutors win 90 percent. Yet Japanese prosecutors win 99.9 percent. ${ }^{3}$ This is not due to any biased judicial incentives: judges do not suffer a career hit for acquitting defendants (Ramseyer and Rasmusen, 2001).

\footnotetext{
${ }^{1}$ Attorney Says He'll Be Candidate for Prosecutor, Indianapolis Star, January 17, 1998, at N02.

${ }^{2}$ Eric W. Bright, "It Isn't Surprising That SEC Missed Madoff's Scam," letter to the editor, The Wall Street Journal, 22 December 2008, http://online.wsj.com/article/SB123000061773329323.html.

${ }^{3}$ The conviction rates of U.S. state prosecutors are obtained from the Census of Prosecutors, 2001, and for federal prosecutors from http://www.ojp.usdoj.gov/bjs/pub/press/fcjt03pr.htm. For Japanese sources, see Ramseyer and Rasmusen (2003), chapter 6.
} 
The contrast between U.S. and Japan holds true even among contested cases. Although Japanese law does not allow plea bargains, defendants can confess, and those who do receive lighter sentences. Among Japanese defendants who did contest their guilt in 2004, 98.4 percent were convicted. Among U.S. federal defendants who contested their guilt in 2003, only 83 percent were convicted. ${ }^{4}$ Japanese courts really do seem tougher.

Might not case selection explain the difference better than toughness? Suppose Japanese prosecutors drop all but their strongest cases. After all, their resources are stretched thin. Japan employs about 1,200 prosecutors. With twice the population, the U.S. employs 32,000. Japan has less crime, but that hardly explains the difference. Each year, police in the U.S. make about 14 million non- traffic arrests - 438 crimes per prosecutor. Japanese police clear about 1.4 million Criminal Code violations per year - 1,166 crimes per prosecutor. The number of crimes is low in Japan, but the number of prosecutors is even lower.

Differences in prosecution rates (prosecutions/crimes) reflect this difference in workload. In 1994, U.S. state courts convicted 870,000 people of felonies, and the federal courts another 44,000. Combining the conviction rates cited earlier and the FBI's index crime arrests figure yields a 42 percent prosecution/arrest ratio. In Japan, by contrast, prosecutors only prosecuted only 14 percent of the 1.4 million people arrested for Criminal Code violations in 2002. The comparison is crude - the crime data is not strictly comparable. But it does suggest that Japanese prosecutors allocate their scarce time to the cases with the strongest evidence. ${ }^{5}$ The lower budget in Japan leads to a lower prosecution rate. Might the lower budget in Japan be raising the conviction rate (convictions/prosecutions)?

In civil cases, Priest and Klein (1984) famously explained how the selection dynamic affected verdict rates. We may observe plaintiffs winning $90 \%$ of the cases, they noted, but that does not tell us about the strength of the plaintiffs' cases generally. Instead, it tells us only about their strength in the subset of cases in which the plaintiffs could not agree with the defendant about what would happen at trial. Quite possibly (but not necessarily), the plaintiffs would have lost most of their claims - but because they knew they would lose they settled out-of-court for small sums.

The same dynamic applies to criminal cases. Conviction rates at trial (convictions/prosecutions) do not tell us about the strength of the prosecutors' cases generally. Instead, the rates tell us only about the strength of those few cases the prosecutor chooses to pursue and the defendant chooses to contest. In the U.S., only $4 \%$ of the defendants go to trial. In the data discussed above, $61 \%$ of the actual trials were bench trials and 39\% jury trials. $85 \%$ ended in guilty verdicts and $15 \%$ in acquittal. ${ }^{6}$ A better measure than conviction rates at trial of a prosecutor's effectivness is his ability

\footnotetext{
${ }^{4}$ Table 12 of http://www.ojp.usdoj.gov/bjs/pub/pdf/fcjt03.pdf

${ }^{5}$ For a dissenting view, see Saxonhouse (2001). For more on the prosecutorial system in Japan, see the book by Johnson (2001).

${ }^{6}$ This implies the percentage of hung juries was close to zero, which is surprising. A different study of state and federal courts found that $6.2 \%$ of juries were hung. Nicole L. Mott, "Part II: The Role of Juries in State Courts," p. 101, Brian Ostrom, Neal B. Kauder, and Robert C. LaFountain, "Examining the Work of State Courts,
} 
to handle plea bargains (which after all, have a greater bearing on the aggregate punishments he is able to obtain): how many defendants plead guilty, and what sentences do they receive?

Rather than examine trial conviction rates, in the article below we look at conviction rates for all cases pursued, whether through plea bargaining or through trial. This has more meaning than trial wins alone, because if a prosecutor does not even pursue a case he has failed to punish the criminal. A high conviction rate might still indicate lenient plea bargains, but he has at least done better than if he had dropped the case. We will also look at a prosecutor's choice of cases to prosecute. In Japan, prosecutors apparently prosecute only the easiest cases, and we ask whether the same a pattern exists in the U.S.

We begin with two models of prosecutorial behavior: (a) a prosecutor who, as social planner, maximizes criminal sentences, and (b) a prosecutor who balances that goal against a high conviction rate and other personal objectives. We then use data on the level of counties and state prosecutor districts to explore the relationship between prosecution rates, conviction rates, and budgets. Ultimately, we show that elected prosecutors may respond to electoral pressure by using resources to raise their conviction rates beyond the levels a social planner would choose, and thereby (by reducing the number of cases pursued) to lower the total punishment imposed.

\section{The Literature on Prosecutors}

A complaint at least as old as Forst \& Brosi (1977) is that prosecutors have been insufficiently studied, either with theory or empirics. That article did build a theoretical model of the prosecutor as attempting to achieve penalties based on the seriousness of the crime and the past record of the criminal given limited resources and the possibility of plea bargaining. Their article built on the simpler model of Landes (1971) and tested the theory with regressions on data at the level of the individual. Other studies have also looked at the variables determining which cases are prosecuted. Myers \& Hagan (1979) and Albonetti, (1986) run regressions on individual case data, and Rainville (2001) uses a survey of 77 prosecutors that asked them about their policies of when to prosecute and when to drop. Boylan (2004) looks at the internal workings of federal prosecutor offices and finds that more experienced U.S. Attorneys put priority on crimes that have longer prison sentences. Glaeser, Kessler \& Piehl (2000) look at how cases are handled depending on whether the defendant is represented by private counsel instead of a public defender. They find that in districts with high lawyers' salaries, defendants represented by private counsel are more likely to be prosecuted by assistant U.S. attorneys than by state and local prosecutors.

The closest paper to the present one is Rhodes (1976). Rhodes looks at how the prosecutor uses increased budget to bring more prosecutions and reduce the leniency of his plea bargains.

2001"(Williamsburg, VA: National Center for State Courts, 2002) http://www.ncsconline.org/D_Research/csp/ 2001_Files/2001_Part_II_Section.pdf. 
He uses data from 84 federal district courts to run regressions of case dispositions on prosecutor resources and variables such as the fraction of defendants with criminal records in the district. He acknowledges the endogeneity problem for the budget, but does not attempt to instrument for it.

Boylan (2005) has examined the incentives of federal prosecutors by seeing what affects the likelihood that U.S. Attorneys (the chief attorneys in federal prosecution offices) later become federal judges, a common career goal for them. He finds that a prosecutor's conviction rate and number of indictments do not affect prosecutor's success, but the number of prison months achieved does matter. As we will see, the results of Boylan (2005) tend to support our model below of the prosecutor acting purely in the public interest, in his special context of U.S. federal prosecutors. Federal prosecutors are appointed, not elected, and the crimes they prosecute are different from those in the state courts, so in the empirical work below we should not be surprised if state prosecutors are differently rewarded.

Miceli (1996) makes the important point that prosecutors (like judges) might well care about fair sentences but not about deterrence, in contrast to legislatures. Thus, prosecutors might frustrate Becker-style high penalties, infrequently imposed and cheap to administer, because those penalties seem unfair for the individual criminals who do get caught. Snyder (1990) looks empirically at one example where prosecutors and courts might be expected to differ from the legislature: their response to an increase by Congress in penalties for federal antitrust laws.

Other work exists on optimal prosecution, but that is a rather different topic than prosecutors themselves. Miceli (1990), for example, looks at how prosecutors and judges (together) should behave when the guilt of defendants is uncertain. That is an important topic, but it is a different one from the decision of how to allocate resources or operate under institutional constraints. Much economic analysis has also been done concerning plea bargaining (e.g. Adelstein (1978a, 1978b), Reinganum (1988, 1993), and Baker and Mezzetti (2001)), but less on the career incentives of prosecutors as agents of the public. One exception is Huber and Gordon (2002), which formally models the incentives of elected prosecutors. They focus on what performance measure voters should reward in order to induce the prosecutor to investigate the guilt or innocence of defendants rather than bring to court cases he knows are dubious. In the present model, our focus will be quite different: it will be on the prosecutor's decision, forced by limitations of time and resources, to drop some cases, prosecute others, and to prosecute some more intensely than others.

\section{A Model with the Social Planner as Prosecutor}

In this section, we construct a model of prosecutorial decisionmaking, in which there are no agency problems: the prosecutor is the social planner. ${ }^{7}$ There is a continuum of potential cases that could be prosecuted, all involving the same crime. ${ }^{8}$ Thus, each case has little importance compared

\footnotetext{
${ }^{7}$ The starting point for this model is the graphical argument in Appendix A, Chapter 6 of Ramseyer and Rasmusen (2001). This model formalizes that argument and extends it to consideration of agency slack, length of sentence, and the conviction rate.

${ }^{8}$ The assumption of a single type of crime is innocuous. If there were $n$ types of crime, with different values
} 
to the aggregate. Potential cases will be indexed by "strength," $\theta$, where $\theta$ varies from 0 to 1 . The number of cases of type $\theta$ is represented by a density function $f(\theta)$, where $\int_{0}^{\infty} f(\theta) d \theta=1$, which is to say that we will normalize so the universe of possible cases has size 1 . Figure 1 shows one way the cases might be distributed. If the prosecutor decides to prosecute the strongest $1 / 3$ of cases, he takes all the cases in the interval $[\bar{\theta}, 1]$ in the diagram. ${ }^{9}$ We will assume that the prosecutor has no evidence of innocence that he can conceal from the court, so a case being "strong" also means that the defendant is more likely guilty, and that the resources available to the prosecutor are low enough that he is far from being able to prosecute cases too weak to be worth prosecuting from a social point of view. (Put differently, we will assume that social welfare is maximized by spending the entire prosecutorial budget rather than leaving some unspent.)

Density, $f(\theta)$

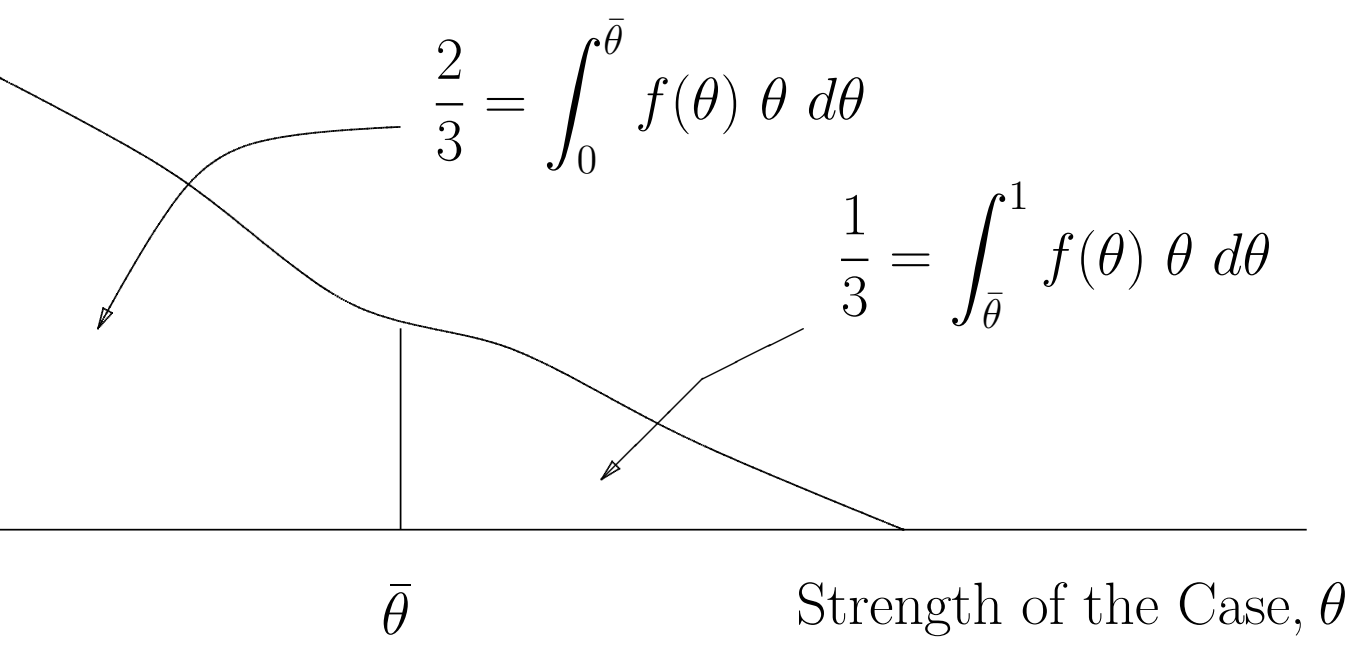

for conviction, we would simply repeat the same objective $n$ times with different production functions and a value coefficient for each, e.g, a tough conviction function but a value of 10 for convicting a murderer, an easy conviction function but a value of 2 for convicting a thief.

${ }^{9}$ We will assume that the interval $[0,1]$ only includes cases the prosecutor would like to win. Thus, a case having $\theta=.1$ does not mean the defendant was less likely to have committed the crime, only that the prosecutor's evidence is weak. As with adding different types of crimes, adding concerns about whether convictions for some crimes are really in the public interest would not alter the model's implications. 


\section{Figure 1: The Distribution of Cases}

Each case that is prosecuted incurs a fixed $\operatorname{cost}$ of $C$ and a variable cost of $e$. Let the probability of winning a case be

$$
\text { Probability of winning }=\theta P(e(\theta))
$$

where $P(0)=0, P^{\prime}>0, P^{\prime \prime}<0$, and $P(\infty)<1$, so additional effort always helps but there are decreasing returns to effort in a particular case and the prosecutor can never be sure of winning.

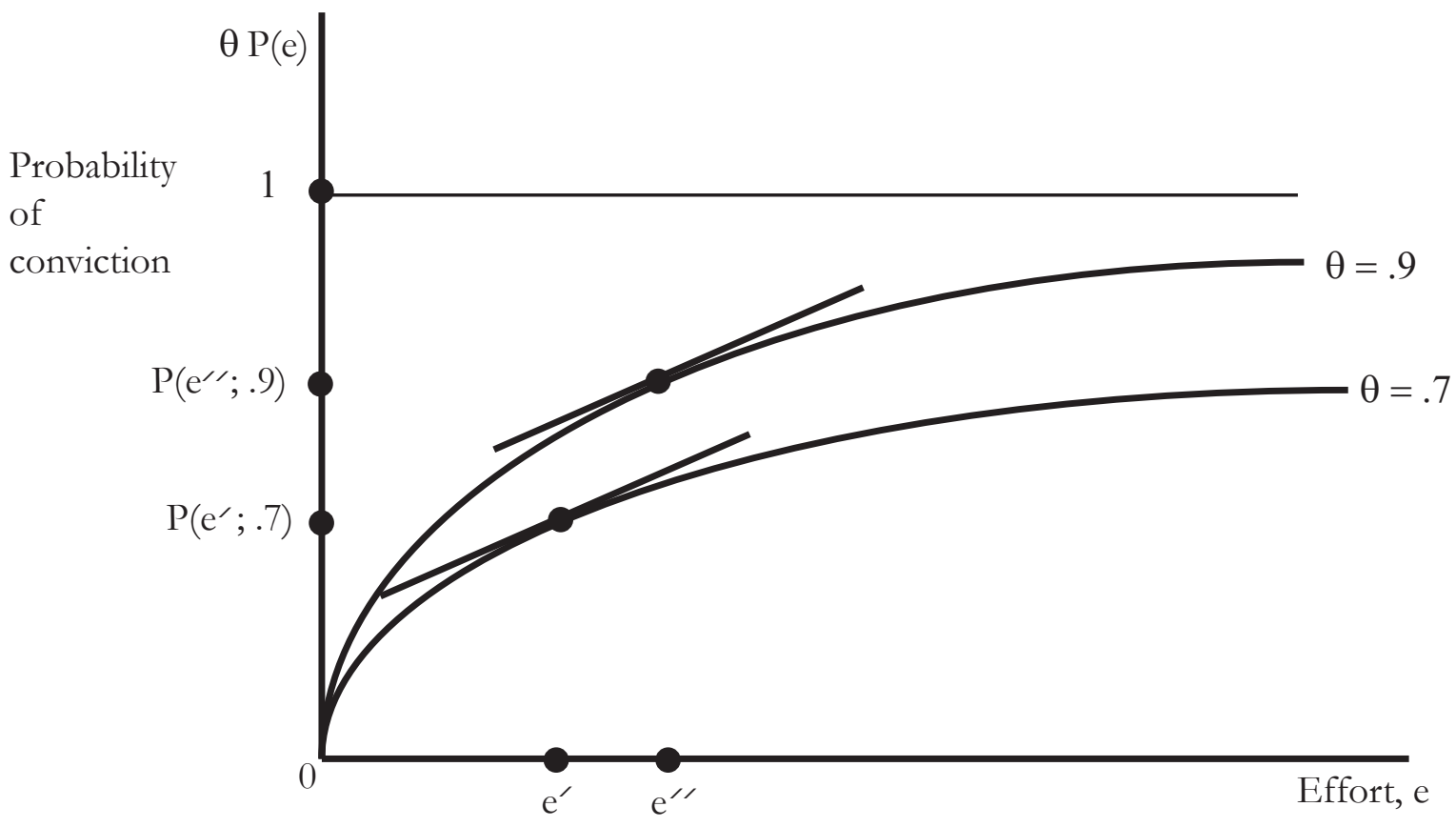

Figure 2: The Conviction Function

These assumptions say that the probability of winning is scaled up or down by case strength, $\theta$, as shown in Figure 2. If effort is the same for two types of case, the type with the bigger $\theta$ has 
the greater probability of winning. ${ }^{10}$

Let the social planner's ideal sentence be $\bar{V}$, and the expected penalty for a case of strength $\theta$ be

$$
\text { Expected Penalty }=\theta V(e(\theta))
$$

where $V(0)=0, V^{\prime}>0, V^{\prime \prime}<0$, and $V(\infty)<\bar{V}$, so additional effort always helps, but there are decreasing returns to effort in a particular case and no amount of effort can achieve the optimal penalty. $^{11}$

We have assumed that the social planner's ideal sentence is $\bar{V}$. Let us denote his valuation of an expected sentence of $\theta S$ by $\theta U(S)$ with $U^{\prime}>0$ and $U^{\prime \prime}<0$ in the range $[0, \bar{V}]$, so the penalty has diminishing marginal returns. We can then write $\theta V(e(\theta)))=\theta U(S(e(\theta)))$ for the expected value to the social planner of exerting effort $e$ on case $\theta$, where $V(0), V^{\prime}>0 V^{\prime \prime}<0$, since $V$ is an increasing concave function of another increasing concave function.

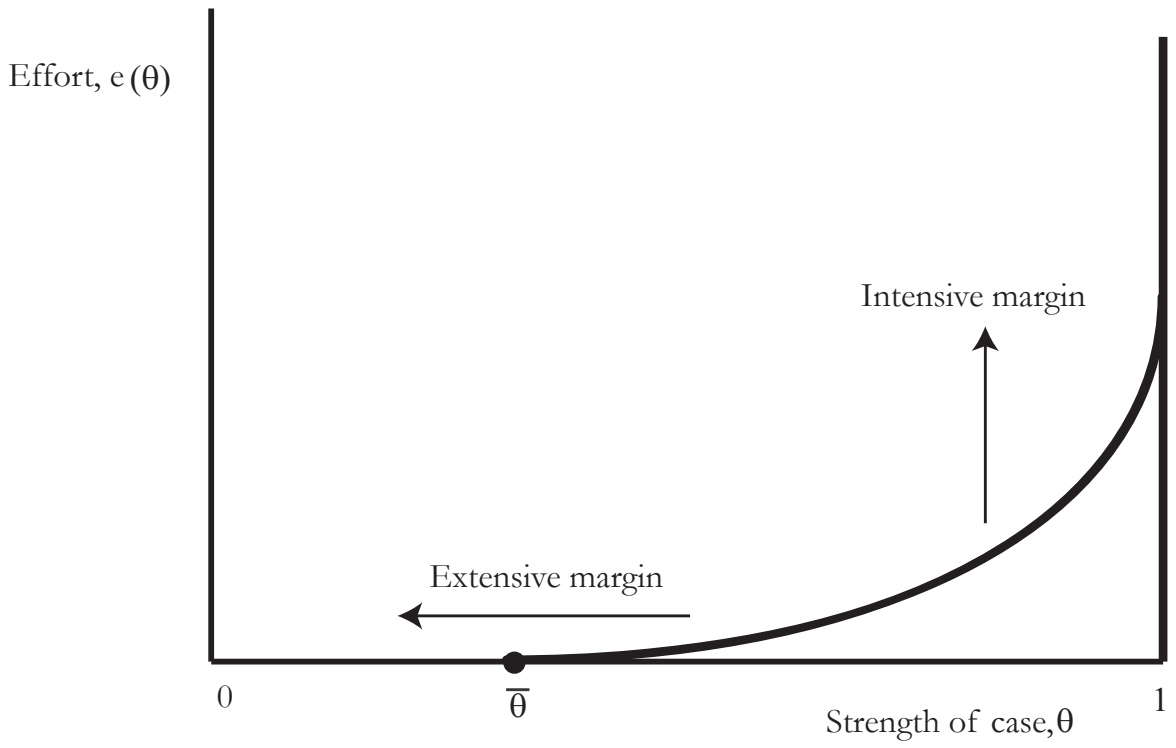

\section{Figure 3: The Prosecutor's Choices of $e(\theta)$ and $\bar{\theta}$}

\footnotetext{
${ }^{10}$ The specification also implies that if effort is the same for two types of cases, the marginal product of effort is bigger for the case with the bigger $\theta$, as illustrated by the tangents in Figure 2. That effect is not important to our results.

${ }^{11}$ We are ruling out the possibility that the social planner would exert high effort so as to fool the court into imposing a sentence higher than $\bar{V}$ with some probability, thus putting the expected sentence at $\bar{V}$.
} 
We now come to our social planner prosecutor's problem. He has two choices. First, he must decide which cases to prosecute. He will want to prosecute the easier cases first, which amounts to choosing a lower cutoff $\bar{\theta}$ for the interval of types $[\bar{\theta}, 1]$ that he prosecutes. The spending on this weakest case prosecuted is the extensive margin, analogous to the least fertile land that under cultivation. Second, he needs to pick the $e(\theta)$ function, which shows how much he spends on each type $\theta$ of case. this is the intensive margin, analogous to the marginal unit of fertilizer used on cultivated land. Figure 3 shows these choices graphically. His decisions lead to the following four expressions.

$$
\begin{gathered}
\text { Prosecution rate }=\int_{\bar{\theta}}^{1} f(\theta) d \theta=1-F(\bar{\theta}) . \\
\text { Number of convictions }=\int_{\bar{\theta}}^{1} f(\theta) \theta P(e(\theta)) d \theta . \\
\text { Value of convictions }=\int_{\bar{\theta}}^{1} f(\theta) \theta V(e(\theta)) d \theta . \\
\text { Conviction Rate }=\left(\frac{1}{1-F(\bar{\theta})}\right) \int_{\bar{\theta}}^{1} f(\theta) \theta P(e(\theta)) d \theta
\end{gathered}
$$

The prosecution rate sums up the amount of case density, $g$, above the prosecution threshold, $\bar{\theta}$. In Figure $1,(1-F(\bar{\theta}))=1 / 3$.

The number of convictions sums up over all the prosecuted cases (those on interval $[\bar{\theta}, 1]$ ) the density $f$ of the number of cases of each type, times the probability of conviction for that type, $\theta P$.

The value of convictions sums up over all the prosecuted cases (those on interval $[\bar{\theta}, 1]$ ) the density $f(\theta)$ of the number of cases of each type, times the value of convictions for that type, $\theta V$.

The conviction rate is the average probability that a prosecution results in a conviction (which will be larger than the probability that a crime results in a conviction). It divides the probability of convictions from equation (4) by the number of cases prosecuted, from equation (3).

What is the prosecutor's payoff function? Let us start with the social planner as prosecutor. He would maximize the value of the expected penalties, i.e.,

$$
\int_{\bar{\theta}}^{1} f(\theta) \theta V(e(\theta)) d \theta
$$

by choice of $e(\theta)$ and $\bar{\theta}$, subject to the budget constraint,

$$
\int_{\bar{\theta}}^{1} f(\theta)[e(\theta)+C] d \theta \leq B .
$$


The Lagrangian for the maximization problem is

$$
\begin{aligned}
\underset{e(\theta), \bar{\theta}}{\text { Maximize }} \quad L & =\int_{\bar{\theta}}^{1} f(\theta) \theta V(e(\theta)) d \theta \\
& +\lambda\left\{B-\int_{\bar{\theta}}^{1} f(\theta)[e(\theta)+C] d \theta\right\} .
\end{aligned}
$$

Note that

$$
\frac{d L}{d B}=\lambda
$$

which is to say that $\lambda$ equals the marginal value of relaxing the budget constraint.

There are two optimality conditions if we are at an interior solution (that is, if not all or no cases are prosecuted). First, there is the choice of the $e(\theta)$ function. For each value $\theta$ in the interval of prosecuted cases, $[\bar{\theta}, 1]$,

$$
\frac{d L}{d e(\theta)}=f(\theta) \theta V^{\prime}(e(\theta))-\lambda f(\theta)(1)=0
$$

Rearranging, we see that the marginal payoff of effort has to be the same for each case prosecuted. For any $\theta$,

$$
\theta V^{\prime}(e(\theta))=\lambda
$$

The second optimality condition concerns the choice of $\bar{\theta}$. It says that

$$
\frac{d L}{d \bar{\theta}}=-f(\bar{\theta}) \bar{\theta} V(e(\bar{\theta}))+\lambda f(\bar{\theta})[e(\bar{\theta})+C]=0
$$

This implies that

$$
\frac{\bar{\theta} V(e(\bar{\theta}))}{e(\bar{\theta})+C}=\lambda
$$

The amount $(e(\bar{\theta})+F)$ is the total cost of a case of the marginal strength $\bar{\theta}$, and $\bar{\theta} V(e(\bar{\theta}))$ is the total benefit. Thus, we have that $\lambda$ equals the average cost of the marginal case. Moreover, since we found earlier that the marginal benefits of all cases prosecuted are equal and equal to $\lambda$, we can conclude that the marginal benefit of any case prosecuted equals the average benefit of the marginal case.

This implies that at the margin, the prosecutor would get the same benefit from adding a new case as he would from increasing spending on an existing case. It also implies that as his budget increases (which reduces $\lambda$ ) he will prosecute more cases as well as spending more on existing cases. 
The result will be to increase the expected penalty from both the new cases brought and the increase in success of the old cases. Formally:

Proposition 1: In the Social Planner Model, an increase in the budget, B, increases effort on existing cases $(e(\theta)$ for $\theta>\bar{\theta})$, increases the prosecution rate (reduces $\bar{\theta}$ ), and increases the size of the expected penalty.

Proof. We will use the implicit function theorem. First, differentiating first-order condition (11) gives us:

$$
\frac{d^{2} L}{d e(\theta)^{2}}=f(\theta) \theta V^{\prime \prime} e(\theta)<0
$$

and

$$
\frac{d^{2} L}{d e(\theta) d \lambda}=-f(\theta)<0
$$

Since

$$
\frac{d e(\theta)}{d \lambda}=-\left(\frac{\frac{d^{2} L}{d e(\theta) d \lambda}}{\frac{d^{2} L}{d e(\theta)^{2}}}\right)=-\left(\frac{-f(\theta)}{f(\theta) \theta V^{\prime \prime}(e(\theta))}\right),
$$

we can conclude that $\frac{d e(\theta)}{d \lambda}<0$. Equation (10) and the concavity of $L$ tells us that $\lambda$ falls with $B$. Thus, $\frac{d e(\theta)}{d B}>0$.

Second, dividing first-order condition (13) by $f(\bar{\theta})$, we know it is true that we can define a variable $Z$ such that

$$
Z=-\bar{\theta} V(e(\bar{\theta}))+\lambda[e(\bar{\theta})+F]=0
$$

Differentiating expression (18) and substituting from equation (12) for $\bar{\theta} V^{\prime}(e(\bar{\theta}))$ yields

$$
\begin{aligned}
\frac{d Z}{d \bar{\theta}} & =-V(e(\bar{\theta}))-\bar{\theta} V^{\prime}(e(\bar{\theta})) e^{\prime}(\bar{\theta})+\lambda e^{\prime}(\bar{\theta}) \\
& =-V(e(\bar{\theta}))-\lambda e^{\prime}(\bar{\theta})+\lambda e^{\prime}(\bar{\theta}) \\
& =-V(e(\bar{\theta}))>0
\end{aligned}
$$

and

$$
\frac{d Z}{d \lambda}=e(\bar{\theta})+C>0
$$

Since

$$
\frac{d \bar{\theta}}{d \lambda}=-\left(\frac{\frac{d Z}{d \lambda}}{\frac{d^{Z}}{d \bar{\theta}}}\right)=-\left(\frac{-V}{e(\bar{\theta})+C}\right),
$$

we can conclude that $\frac{d \bar{\theta}}{d \lambda}>0$. Equation $(10)$ and the concavity of $L$ tell us that $\lambda$ falls with $B$. Thus, $\frac{d \bar{\theta}}{B}<0$. 
Finally, the amount of expected penalty rises because it is an increasing function of $e(\theta)$ and a decreasing function of $\bar{\theta}$ ). Q.E.D.

We cannot, however, say how an increase in the budget will affect the conviction rate.

Proposition 2: In the Social Planner Model, an increase in the budget, B, might either increase or reduce the conviction rate.

Proof. From equation (6) the conviction rate is

$$
\left(\frac{1}{1-F(\bar{\theta})}\right) \int_{\bar{\theta}}^{1} f(\theta) \theta P(e(\theta)) d \theta
$$

We have seen in Proposition 1 that when the budget increases, $\bar{\theta}$ falls (reducing the conviction rate) and $e(\theta)$ rises (increasing the conviction rate). Since these changes have opposite effects on expression (6), the outcome is ambiguous. From the proof of Proposition 1, the effect of $\bar{\theta}$ is proportional to $\frac{V}{e(\bar{\theta})+C}$ for marginal changes. Thus, if the fixed cost $C$ is large enough, the change in $\bar{\theta}$ will have little impact, and the conviction rate will rise. The proof of Proposition 1 also tells us that the effect of changes in $e(\theta)$ is proportional to $\frac{1}{\theta V^{\prime \prime}(e(\theta))}$. Thus, if $V^{\prime \prime}(e(\theta))$ is large enough for all $e(\theta)$, the change in $e(\theta)$ will have little impact, and the conviction rate will fall. Thus, depending on $C$ and $V^{\prime \prime}$ the conviction rate might increase or might fall after a budget increase. Q.E.D.

Proposition 2 says that the conviction rate can fall because two things matter as the budget $B$ increases. First, how big is the fixed cost of prosecuting a case, $C$ ? If it is big, then most of the extra budget will go to existing cases, and the conviction rate will rise, not fall. Second, how big is $\bar{\theta} V^{\prime \prime}(e(\bar{\theta})$, the change in the marginal product of spending on existing cases? If it is very negative, then there are sharply diminishing returns to increased spending on existing cases. As a result, the average probability of success should fall when the budget rises, because the extra money goes mostly to prosecute new, weaker, cases.

An increase in the fixed cost $C$ is similarly ambiguous. It will certainly increase $\bar{\theta}$, reducing the prosecution rate (which is easily proved using the method of Proposition 1 and the fact that $\left.\frac{d Z}{d C}=\lambda>0\right)$. It reduces the amount of variable effort $e$ that the prosecutor can expend for a given number of prosecutions, so the effect on his objective, total value of prosecutions, cannot but be negative. The effect of a higher fixed cost on the conviction rate, however, is ambiguous. The average product of the marginal case will fall, and the prosecutor will shift resources towards the other cases. He has to spend more on the fixed cost of those cases, so we cannot tell in the end, however, whether spending on the marginal effort $e$ increases or falls. Normal intuition tells us that the conviction rate should fall if costs rise, but if it is a fixed cost, that might not be the case. Instead, it could happen that the prosecution rate falls so much that enough resource are freed up for the remaining cases that the conviction rate rises.

Particularly surprising is the possibility that having juries more hostile to police and prosecutors 
might raise the conviction rate. This can be interpreted as an increase in $C$ if it means more must be spent to attain even a base-level probability of success. The effect of a district having more skeptical juries might as a result be to make prosecutors more selective about which cases they bring, to such an extent that they win a higher fraction of them. This is just one way in which skeptical juries could enter the model, and the way they affect variable costs, fixed costs, and the probability of success is crucial. If the effect is to multiply the expected penalty $\theta V(\theta)$ by a constant such as 0.8 , for example, the conviction rate will fall without any effect on the prosecution rate or the allocation of effort. But the possible perverse effect of $C$ on shows how difficult it would be to predict the effect of variables such as political climate on conviction rates. We must resort to empirical estimation unless we are willing to make assumptions about how the prosecution rate affects the conviction rate.

\section{The Political Model: The Prosecutor as Agent of the Voters}

When the prosecutor uses the social welfare function for his payoff, we can at least predict the effect of a budget change on the prosecution rate, if not the conviction rate. Once agency problems are introduced, even this becomes difficult. Two central problems in any principal-agent relationship are that (a) the agent will want to use his effort for personal goals unrelated to the principal's goal, and (b) if the principal rewards the agent based on a rough proxy for the principal's true objective, the agent will pursue the proxy and not the real thing. The more the principal tries to solve problem (a) with a high-powered incentive contract, the more he must worry about problem (b). Here, the principal is the public and the agent is the prosecutor. Problem (a) takes the form of the prosecutor wanting to use his office's resources for things such as perks for himself, higher wages for his subordinates, and prosecutions or other use of office personnel that are intended to further his post-prosecutorial career in the public or private sector. Problem (b) takes the form of the prosecutor focusing too much on variables the principal can measure well and too little on other goals.

Here, we will focus on the conviction rate as that well-measured variable, something some voters will reward despite its imperfections as a measure of performance. Prosecutor agents must please their principals, however, whether they are appointed or elected, and they have personal objectives too. If the prosecutor must run for reelection his payoff function may also include the conviction rate, as suggested in the Introduction. An elected prosecutors - and perhaps appointed an one too - must appeal to people who do not know how many potential cases exist, and so have difficulty evaluating the number of convictions he achieves, not to mention the average sentence for those convictions. The absolute number of prosecutions is by itself meaningless to a voter, and even the prosecution rate is not a helpful number given the small number of arrests and prosecutions that occur anywhere in the United States relative to the amount of crime. A conviction rate, however, conveys some meaning, and will have even more impact on voters who have not thought of the effect of careful selection of 
which cases to prosecute. It will not be the only variable that affects voters- if the prosecution rate falls enough, the change will be noticeable, and by continuity even a small change will have some impact on voters; if a person had absolutely no perception of a temperature decline of one degree, he could not perceive a decline of fifty degrees either. But voters, even more than administrative superiors, will look to clear measures such as conviction rates, as Gordon \& Huber (2002) argue. We might expect that if an elected prosecutor's term of office is short or the degree of political competition is high, the prosecutor would put more weight on acquiring a high conviction rate. Conviction rates should thus be correlated with short terms or frequent turnover in the office, something we will look at below.

We will put these two agency problems together into what we will call the Political Model. If we denote effort spent on personal goals as $e_{a}$ and the utility of personal goals and slack as $S\left(e_{a}\right)$ with $S^{\prime}>0$ and $S^{\prime \prime}<0$ (so increased effort devoted to slack has diminishing marginal utility), we can write the payoff function as

$$
\begin{aligned}
\text { Payoff(prosecutor })= & U[\alpha(\text { conviction rate }),(1-\alpha) \beta(\text { personal goals }), \\
& (1-\alpha)(1-\beta)(\text { convictions })] \\
= & U\left[\alpha W[e(\theta), \bar{\theta}],(1-\alpha) \beta S\left(e_{a}\right),(1-\alpha)(1-\beta) C[e(\theta), \bar{\theta}]\right],
\end{aligned}
$$

where

$$
W=\left(\frac{1}{1-F(\bar{\theta})}\right) \int_{\bar{\theta}}^{1} f(\theta) \theta P(e(\theta)) d \theta \quad C=\int_{\bar{\theta}}^{1} f(\theta) \theta V(e(\theta)) d \theta
$$

In the Political Model payoff function, $\alpha$ parameterizes the importance of a high conviction rate to the prosecutor and $\beta$ parameterizes the importance of low effort spent on prosecutions, where if $\alpha=\beta=0$ we return to the original model of the social planner. These parameters have been introduced in a particular way. The parameter $\alpha$ represents political pressure by voters who vote on the basis of the conviction rate. To the extent that the prosecutor does not care about them, $(1-\alpha)$, his payoff is split between slack effort and the number of convictions. Thus, a way to represent loose political pressure is a low value of $\alpha$, and a way to represent a prosecutor who will follow the public interest if he is not under political pressure is with a low value of $\beta$.

The budget constraint changes also, to reflect the cost to the budget of effort on personal goals:

$$
e_{a}+\int_{\bar{\theta}}^{1} f(\theta)[e(\theta)+C] d \theta \leq B .
$$


The Lagrangian for the maximization problem is

$$
\begin{aligned}
e_{a}, e(\theta), \bar{\theta} \quad L= & U\left[\alpha W[e(\theta), \bar{\theta}],(1-\alpha) \beta S\left(e_{a}\right),(1-\alpha)(1-\beta) C[e(\theta), \bar{\theta}]\right] \\
& +\lambda\left\{B-e_{a}-\int_{\bar{\theta}}^{1} f(\theta)[e(\theta)+C] d \theta\right\} .
\end{aligned}
$$

The Political Model has three optimality conditions. First, there is the choice of agency slack, $e_{a}$ :

$$
\frac{d L}{d e_{a}}=U_{2}(1-\alpha) \beta S^{\prime}-\lambda=0
$$

The first optimality condition says that the prosecutor's gain from extra slack must equal its cost in terms of foregone budget that might have been spent on a higher conviction rate or more convictions.

Second, there is the choice of the $e(\theta)$ function. For each value $\theta$,

$$
\frac{d L}{d e(\theta)}=U_{1}\left(\frac{\alpha}{1-F(\bar{\theta})}\right) f(\theta) \theta P^{\prime}+U_{3}(1-\alpha)(1-\beta) f(\theta) \theta V^{\prime}-\lambda f(\theta)(1)=0 .
$$

Rearranging and combining these last two conditions, we see that the marginal payoff of effort must be the same for each case prosecuted, as in the social planner model, though now the payoff is more complicated. For any $\theta$,

$$
U_{2}(1-\alpha) \beta A^{\prime}=U_{1}\left(\frac{\alpha}{1-F(\bar{\theta})}\right) \theta P^{\prime}+U_{3}(1-\alpha)(1-\beta) \theta V^{\prime}=\lambda .
$$

As $\alpha$ rises, the prosecutor slackens less and puts more effort into each case he chooses to prosecute, for a higher conviction rate. Unlike earlier, however, it is the probability of conviction in a case, $P$, rather than the expected penalty, $V$, which matters, so we would expect the number of generous plea bargains to increase. As $\beta$ rises, more effort is diverted to personal goals, leaving less for prosecutions. As $\lambda$ rises, indicating a greater marginal utility of money and a lower budget, effort per prosecution and slack both fall.

The third optimality condition concerns the choice of $\bar{\theta}$. It says that

$$
\begin{aligned}
\frac{d L}{d \bar{\theta}} & =\alpha U_{1}\left(\left[\frac{f(\bar{\theta})}{(1-F(\bar{\theta}))^{2}} \int_{\bar{\theta}}^{1} f(\theta) \theta P d \theta\right]-\left[\frac{1}{(1-F(\bar{\theta}))}\right] f(\bar{\theta}) \bar{\theta} P(e(\bar{\theta}))\right) \\
& -U_{3}(1-\alpha)(1-\beta) f(\bar{\theta}) \bar{\theta} V(e(\bar{\theta}))+\lambda f(\bar{\theta})[e(\bar{\theta})+C] \\
& =0 .
\end{aligned}
$$


Again the the average payoff of expenditure on the marginal case prosecuted equals $\lambda$, the marginal payoff on any case. At the margin, the prosecutor should get the same benefit from adding a new case as he would from increasing spending on an existing case.

Introducing the conviction rate into the payoff function and allowing the payoff function to have three arguments instead of one means the objective function is no longer concave in the prosecution threshold $\bar{\theta}$. Indeed, we can say very little now about comparative statics, which is the point of Proposition 3.

Proposition 3: In the Political Model, the conviction rate and prosecution rate might either rise or fall with the budget.

Proof. The conviction rate depends on the number of cases prosecuted, $\bar{\theta}$. Proposition 2 showed that if more cases are prosecuted, the conviction rate can fall. Here, we have changed the objective function by adding the conviction rate directly and by adding slack. If the weight put on these two objectives is chosen to be small enough, then Proposition 2's conclusion will still apply, because the effect of these two objective variables on the optimal choice of control variables is continuous. Thus, the budget has an ambiguous effect on the conviction rate.

We similarly know from Proposition 1 that the prosecution rate might rise with the budget. To prove that it can fall, consider the following example. Suppose that at the level of the choice variables optimized for the initial budget the marginal payoff to the prosecutor of convictions, $C$ is falling in the size of the conviction rate, $W$, so $U_{13}<0$ (e.g. because a higher conviction rate reduces the importance of a high number of convictions to win re-election), and that convictions has greater diminishing payoff than the conviction rate $\left(U_{11}\right.$ is small relative to $\left.U_{33}\right)$. An increase in the budget will then be spent more on increasing the effort on existing cases, increasing the conviction rate, and reducing the value of convictions, so that the optimal $\bar{\theta}$ would fall: fewer prosecutions would result from a higher budget. Q.E.D.

Proposition 2 showed how the conviction rate might either rise or fall with increased budget because the prosecutor might start taking on more difficult cases. What is different in Proposition 3's Political Model is that now the prosecutor has two new objectives besides getting convictions: a high conviction rate, and low personal effort on prosecution. If we reduce the parameters that represent the importance of these new goals to the prosecutor, we will be increasing the importance he puts on convictions. The Social Planner Model is the limit of the Political Model as the importance of the two new goals goes to zero, so we should expect Proposition 2's reasoning for an ambiguous effect of budget on conviction rate to also be possible in the Political Model. We might expect somewhat greater conviction rates in the Political Model because the prosecutor cares directly about the conviction rate, but we also might 
expect both fewer prosecutions and a lower conviction rate because of agency slack.

Proposition 3 also says that it is impossible to say generally how an increase in the budget will affect the prosecution rate. This is surprising, because Proposition 1 said that in the Social Planner Model we could confidently predict that prosecutions would rise with the budget. The reasoning there was that an increase in the budget allowed improvements on two margins, the extensive margin of prosecuting more cases and the intensive margin of prosecuting existing cases more heavily, and that with diminishing returns to each margin some of the extra budget should be devoted to each. The analogous reasoning here would be that although we now have three goals (convictions, conviction rate, and slack) instead of just one (convictions), there are diminishing returns to each and the extra budget should be spent on all three. But that reasoning is fallacious.

The fallacy is that the three goals can interact with each other in complicated ways, unlike the two means (marginal and extensive) to the one goal of maximizing convictions. The prosecutor's choice among goals is like that of a consumer among goods. Just as a higher income can result in a consumer buying less margarine, an inferior good, so a higher budget could result in a prosecutor "buying" fewer convictions. Instead, he might spend all of the increase in his budget, and more, on increasing the conviction rate and advancing his personal goals of slack and non-prosecution goals that aid his re-election.

The theory just laid out tells us that from the normative point of view it is difficult to say whether a prosecutor's conviction rate should be high (from Proposition 2), and from the positive point of view it is hard to predict whether it will increase with the budget (Propositions 2 and 3). If the Social Planner model is not just normative, but also describes how prosecutors behave, then a budget increase will be spent partly on the intensive margin of prosecuting the existing number of cases with extra resources and partly on the extensive margin of prosecuting more cases. The number of prosecutions and convictions will rise, but the conviction rate might fall. The Political Model is a positive model which adds the conviction rate and slack to the prosecutor's objective function. These new goals both conflict with spending on the extensive margin of new prosecutions. As a result, not only does the effect of increased budget on the conviction rate remain ambiguous (Propositions 2 and 3 ), but we cannot even say that the number of prosecutions or convictions will rise (Proposition 3). Thus, when we look at anecdotal or numerical data, if the personal goals of prosecutors depend on the conviction rate we should not be surprised if high budgets are not always associated with high conviction rates.

Proposition 3 does say that in the Political Model the effect of a budget increase is ambiguous for both the conviction rate and the prosecution rate, unlike the effect for 
the prosecution rate in the Social Planner Model stated in Proposition 1. Thus, we can try to test between the two models based on whether prosecutions rise with budgets. Whether the conviction rate rises with the budget is ambiguous in both models, but we would expect the conviction rate to rise more (or fall less) in districts where the Political Model is more likely to apply because prosecutors are elected rather than appointed or where they are elected with shorter terms.

\section{State Prosecutions in the United States}

We can do simple tests for the Social Planner Model versus the Political Model using state-level data from the United States. In 2001, 2,341 prosecutor's offices handled felony cases in state courts of general jurisdiction. They employed some 79,000 people and had a budget of about 4.7 billion dollars. The size of offices increased markedly over the previous decade. From 1994 to 2001, budgets grew $61 \%$ after inflation, and the number of assistant prosecutors grew 26\%. Of these offices, 1,809 employed full-time chief prosecutors and 532 had part-time chief prosecutors (in 29 states), an increase in the number of full-time chief prosecutors to $77 \%$ compared to the $53 \%$ in 1990 . Figure 4 is a map of the districts and also shows which had part-time prosecutors. ${ }^{12} \mathbf{3 \%}$ of the personnel were chief prosecutors, $30.5 \%$ were assistant prosecutors, and the rest were people such as support staff and investigators.

A full $87 \%$ of chief prosecutors were elected or appointed to four- year terms. Chief prosecutors are elected everywhere except Alaska, Connecticut, the District of Columbia, and New Jersey. In Alaska, Delaware, and Rhodes Island, criminal prosecution is the primary responsibility of the state's attorney-general, and in the District of Columbia the U.S. Attorney has jurisdiction over felonies and misdemeanors.

Half of the offices received at least $85 \%$ of their funding from the county government, and a third relied entirely on the county. Half received some state funding, and $6 \%$ had their entire funding from the state. City governments and grant funds also supplied funding.

By definition, these offices handle felonies. The percentages also handling misdemeanors, juvenile matters, and traffic violations were $91 \%, 89 \%$ and $84 \%$. $51 \%$, handled felony appeals (including $77 \%$ of the 34 with district populations of over one million), and $54 \%$ represented the government in civil suits. ${ }^{13}$

\footnotetext{
${ }^{12}$ Figure 4 and the numbers in this and the next three paragraphs are from DeFrances (2002).

${ }^{13}$ The distribution of these by size is interesting. The percentage of full-time prosecutors representing the government in civil suits was $41 \%$ in districts with over a million people, $27 \%$ in districts with between 250,000 and
} 


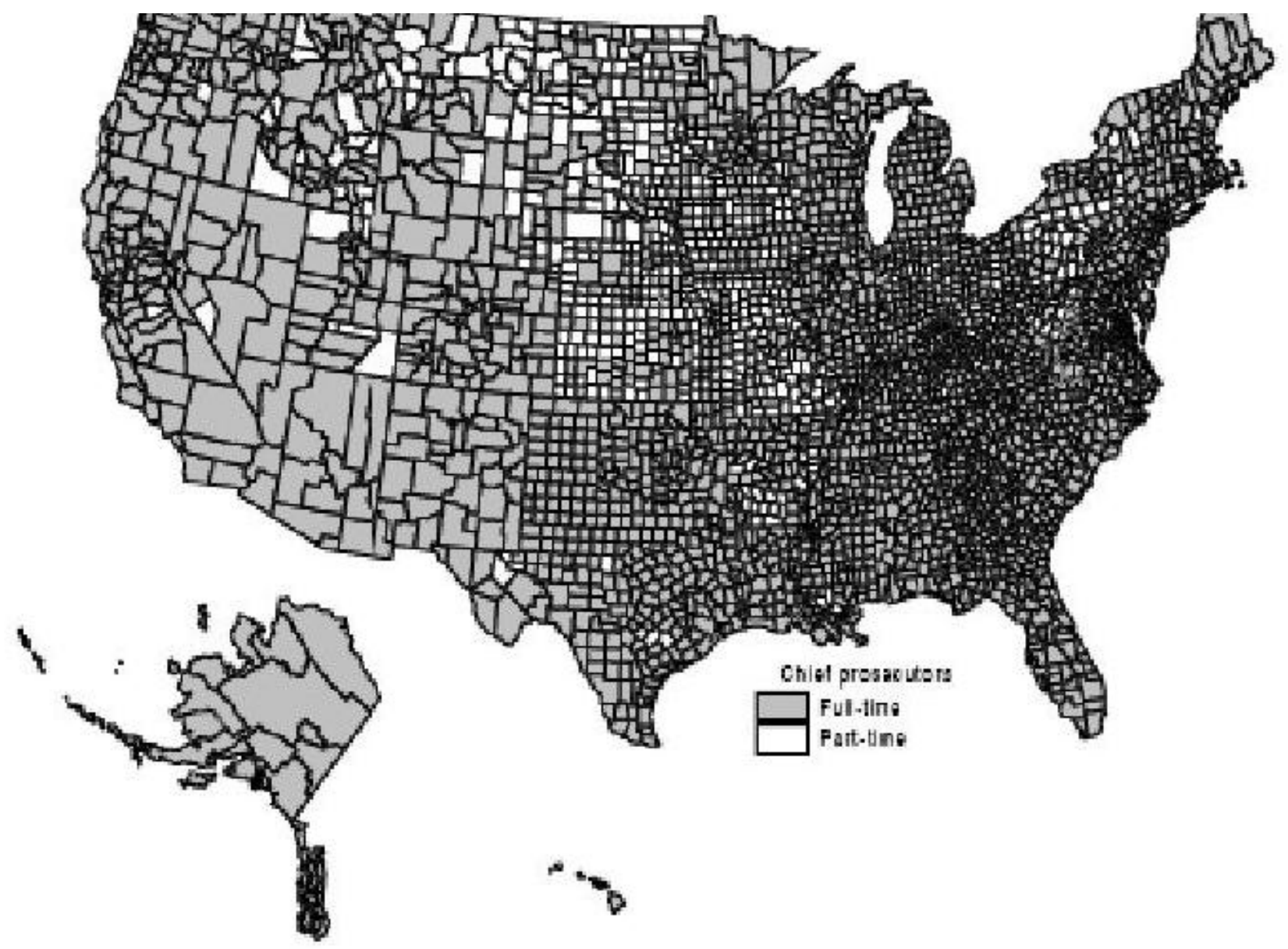

Figure 4: Prosecutorial Districts in the United States

\section{Data and Endogeneity}

If we are to study American prosecutors, our unit of observation should be the state prosecutorial district. These are often the same as counties, but not always. Alaska, for example, has just one prosecutorial district but many counties; and some counties are split between prosecutorial districts.

Our task is see what explains conviction rates and prosecution rates in this data.

$1,000,000$ people, and $51 \%$ in districts with fewer than 250,000 people. The figure for part-time prosecutors, however, was $75 \%$. 
Our source for variables involving prosecutors' offices (e.g. conviction rates, salaries) is the 2001 National Prosecutor's Survey by the Bureau of Justice Statistics, U.S. Department of Justice. This was a mail survey with telephone follow-up. 96\% of the 2,341 offices responded, and 98 did not. The Survey tried to find data on the 98 missing offices from secondary sources such as the county budget office. It also imputed missing values for various variables using the "hot deck" method, which copies values from observations having similar values for non-missing variables. These included 288 values for felony cases closed (DeFrances [2002]). The National Prosecutor's Survey occurs every few years, but in the 1992, 1994, 1996, and 1998 surveys it only included a sample of about 300 districts, not the entire population of districts.

Our second major data source is the 2001 Uniform Crime Reporting Program Data of the Federal Bureau of Investigation, U.S. Dept. of Justice. This is published annually and contains detailed data on the amount of crime reported to police.

The crime data, which is arranged by county, is well known and much used; the prosecutor dataset, arranged by prosecutorial district, is much less known. Our dataset merges them, using the district as the unit of observation.

Another of our variables, a measure of political conservatism, the percentage of the November 2000 presidential vote received by George Bush, is from the Center for Presidential and Congressional Studies at American University. We also obtained demographic information, from the Bureau of Census. This includes information about population, racial composition of counties, per-capita income, median rent, population density, housing density, educational attainment of population in different counties, the age composition of population in different counties, and the total area of each county. Each of these variables was at the county level, which we aggregate to the level of prosecutorial districts that usually consist of several counties.

We conduct empirical investigation to see if the predictions from our theoretical model match the results from the real world. To this end, we run regressions on the conviction rate (felony convictions divided by the number of prosecutions times 100) and the number of felony prosecutions. We use the number of prosecutions rather than the rate because we do not have data for all reported felony crimes, just the number of index crimes, whereas our prosecutions number is for all felonies. We run a tobit regression to explain the conviction rate because it always lies between 0 and 100(\%), but least squares for the number of prosecutions.

The Census of Prosecutors data have some districts for which the conviction rate is greater than $100 \%$ or less than $0 \%$, which we dropped. This deletion is unlikely to introduce bias into our estimates since those districts are spread all over the United States and do not exhibit any peculiar pattern which sets them apart from the other districts. We also dropped the top $5 \%$ of the districts by population. These districts 
are drastically different in size from the rest, ranging in population from 537,000 to 9.51 million compared to a median of 34,000 for the other districts. We are left with 1,625 observations, of which about 1,400 contain values for all the variables we use in the regressions.

Table 1 contains summary statistics for the regression variables. In addition, note that 338 of the districts are in metropolitan areas and 14 of them have appointed prosecutors.

Table 1: Summary Statistics

\begin{tabular}{|c|c|c|c|c|c|c|}
\hline Variable & Mean & Min & 25th & $\begin{array}{r}\text { Percentile } \\
50 \text { th }\end{array}$ & 75th & Max \\
\hline Conviction Rate (\%) & 83 & 0 & 79 & 90 & 96 & 100 \\
\hline Number of Felony Cases Closed & 599 & 1 & 75 & 218 & 573 & 15,639 \\
\hline Prosecutorial Budget $(\$ 1,000 s)$ & 777 & 6 & 125 & 298 & 750 & 15,500 \\
\hline Number of Index Crimes & 457 & 0 & 26 & 131 & 461 & 8,856 \\
\hline Chief Prosecutor's Salary $(\$ 1,000 s)$ & 77 & 11 & 52 & 80 & 99 & 150 \\
\hline Years in Office & 9.14 & 0 & 4 & 7 & 14 & 40 \\
\hline Term of Office & 4.11 & 1 & 4 & 4 & 4 & 10 \\
\hline Population & 444 & 12,905 & 34,010 & $67,577.46$ & 82,341 & 537,484 \\
\hline Presidential Vote for Bush in 2000 (\%) & 59 & 19 & 51 & 58 & 66 & 91 \\
\hline African-American Population & 7,271 & 0 & 60 & 517 & 3,842 & 326,097 \\
\hline
\end{tabular}

The prosecutorial budget and the number of index crimes might be endogenous, influenced by the conviction and prosecution rates. We have accordingly used instrumental variables in our regressions. As instruments for the prosecutorial budget, we have used the aggregate pay of the full time and part time employees and the total personal income of the district's population, both in logs. These instruments are correlated with the prosecutorial budget because the prosecutor gets most of his budget from the local government (a first-stage regression has an $R^{2}$ of .22 and an $F$-statistic significant at well beyond the .01 level). They are beyond his control, unlike the prosecutorial budget, which he can request to increase in response to the difficulty of prosecution or conviction.

As instruments for crime we have used the percentage of males between 15 and 24, 
percentage of people who are employed, percentage of males with no schooling, and housing density, all in logs. A first- stage regression has an $R^{2}$ of .44 and an $F$-statistic significant at well beyond the .01 level. We did not use the percentage of AfricanAmerican population as an instrument of crime because we include it in the main regression because of its possible effect on the conviction and prosecution rates. Since African-Americans are disproportionately both victims and perpetrators of crime, we might well expect a direct effect of race on the prosecutor's conviction rate (as Butler [1995] suggests), though its direction would be unclear.

\section{$5 \quad$ Regression Results}

Proposition 1 says that in the Social Planner Model an increase in the prosecutor's budget increases his prosecution rate for a given crime rate, but Proposition 2 says that his conviction rate might either rise or fall. Proposition 3 says that in the Political Model the effect of a budget increase is ambiguous for both the conviction rate and the prosecution rate. We can test between the two models based on whether prosecutions rise with budgets. Whether conviction rates rise with budgets is ambiguous in both models, but we would expect the conviction rate to rise more (or fall less) in districts where the Political Model seems more likely to apply because prosecutors are elected rather than appointed or where they are elected with shorter terms.

Table 2 looks at how the conviction rate is related to the prosecutor's budget, the number of prosecutions, and other variables. Regression (1) uses tobit. Regression (2) uses tobit with instrumental variables for both budget and crime as described above, while Regression (3) instruments only for the prosecutorial budget. Maximization of the likelihood in regression (2) would not converge, so Stata's two-step estimator was used instead. The coefficients from two-step regressions are not comparable to the standard maximimum likelihood technique, but it is valid for the purpose of testing the instruments. A Wald chi-squared test applied to regression (2) cannot reject the exogeneity of budget and crime. We therefore prefer regression (3), in which only the budget is endogenous, and where a Wald test does reject exogeneity of the budget (at the $2.1 \%$ significance level). ${ }^{14}$ We also tested the residuals from (3) for correlation with district population and found no significant correlation.

In regression (3), the conviction rate does rise with the budget, keeping the number of prosecutions (the "cases closed" variable) constant. The statistical significance is well above the $5 \%$ level. If one calculates the elasticities of how the conviction rate changes with respect to the budget, (using the STATA mfx command evaluated at the medians), it is 0.11 : a $10 \%$ rise in the budget increases the conviction rate by $1.1 \%$.

\footnotetext{
${ }^{14} \mathrm{~A}$ Wald test on a regression which instrumented only for crime (unreported here) could not reject its exogeneity.
} 
If the conviction rate is at the median of $90 \%$, a rise in the number of prosecutions by $10 \%$ will increase it to $90.90 \%$. That amount may not seem large, but given the high rate of diminishing returns we would expect in the process of prosecution it is not surprising. We should note, too, that in regression (1), which assumes that the prosecutor's budget does not depend on the desired conviction rate, the budget is not statistically significant as an influence on the conviction rate.

The conviction rate also falls with the number of prosecutions (the "cases closed" variable), at a very significant level statistically. This is not an implication of the theory, but one of its assumptions. Yet if one calculates the elasticity of how the conviction rate changes with respect to prosecutions, it is only -0.031 : a $10 \%$ rise in the number of prosecutions reduces the conviction rate by $.31 \%$. If the conviction rate is at the median of $90 \%$, a rise in the number of prosecutions by $10 \%$ will reduce it to about $87.27 \%$. What our statistical significance establishes is that the size of the effect is definitely small, if nonzero. This implies that in the average United States district the prosecutor has a large enough stock of potential cases that increasing his number of prosecutions would scarcely reduce his conviction rate. We conclude from the budget and number of prosecutions coefficients that the chief limiting factor for the number of prosecutions is the fixed cost of an additional prosecution.

The chief prosecutor's salary and years in office are insignificant in Table 2. Whether the chief prosecutor is appointed is highly significant, both statistically and in magnitude. As the Political Model would predict, appointed prosecutors, less worried about poorly informed public opinion, have lower conviction rates. The Political Model predicts that the effect of a longer term of office would also be negative because it would ease voter pressure, but it comes in positive and marginally significant at the $10 \%$ level. We have no explanation for this.

The other variables in the regression are control variables which do not help distinguish between the Social Planner Model and the Political Model. The amount of crime reduces the conviction rate in specification (3). The values of the other control variables are insignificantly different from zero except for the regional dummy South, which has a positive effect on the conviction rate (at the $5.4 \%$ significance level). In particular, the percentage of the population that is black does not significantly increase or reduce the conviction rate. 
Table 2: Explaining the Conviction Rate

(1)

\begin{tabular}{|c|c|c|c|}
\hline Prosecutorial Budget (\$ millions) & $\begin{array}{r}0.13 \\
(0.21)\end{array}$ & $\begin{array}{r}-7.07 \\
(1.18)\end{array}$ & $\begin{array}{r}27.32^{* *} \\
(2.31)\end{array}$ \\
\hline Number of Felony Cases Closed $(1,000 s)$ & $\begin{array}{r}-2.72^{* * *} \\
(3.96)\end{array}$ & $\begin{array}{r}-0.71 \\
(0.45)\end{array}$ & $\begin{array}{r}-.01 * * * \\
(2.15)\end{array}$ \\
\hline Chief Prosecutor's Salary $(\$ 10,000 s)$ & $\begin{array}{r}-0.56^{* *} \\
(2.43)\end{array}$ & $\begin{array}{r}0.13 \\
(0.30)\end{array}$ & $\begin{array}{r}-.01 \\
(1.27)\end{array}$ \\
\hline Chief Prosecutor Appointed (= 1) & $\begin{array}{l}-4.56 \\
(0.71)\end{array}$ & $\begin{array}{r}21.39 \\
(0.90)\end{array}$ & $\begin{array}{r}-114^{* *} \\
(2.29)\end{array}$ \\
\hline Years in Office & $\begin{array}{r}0.15^{*} \\
(1.96)\end{array}$ & $\begin{array}{r}0.18^{* *} \\
(2.09)\end{array}$ & $\begin{array}{r}0.11 \\
(0.92)\end{array}$ \\
\hline Term in Office & $\begin{array}{r}1.06 \\
(1.59)\end{array}$ & $\begin{array}{r}0.79 \\
(1.09)\end{array}$ & $\begin{array}{c}1.70^{*} \\
(1.65)\end{array}$ \\
\hline Number of Index Crimes $(1,000 s)$ & $\begin{array}{r}0.13 \\
(0.13)\end{array}$ & $\begin{array}{r}7.39 \\
(1.02)\end{array}$ & $\begin{array}{r}-23.55^{* *} \\
(2.11)\end{array}$ \\
\hline Metropolitan Area $(=1)$ & $\begin{array}{l}-1.26 \\
(0.87)\end{array}$ & $\begin{array}{r}-2.75 \\
(0.87)\end{array}$ & $\begin{array}{r}2.75 \\
(1.14)\end{array}$ \\
\hline African-American Population (\%) & $\begin{array}{r}-0.07 \\
(1.33)\end{array}$ & $\begin{array}{l}-0.21^{*} \\
(1.73)\end{array}$ & $\begin{array}{r}0.35 \\
(1.52)\end{array}$ \\
\hline Constant & $\begin{array}{r}85.37 * * * \\
(25.81)\end{array}$ & $\begin{array}{r}82.95 * * * \\
(23.79)\end{array}$ & $\begin{array}{r}75.59 * * * \\
(17.08)\end{array}$ \\
\hline
\end{tabular}

Notes: In parenthesis are z-statistics. *, **, and *** indicate significance at the $\mathbf{1 0 \%}, \mathbf{5 \%}$, and $1 \%$ levels. All regression use tobit with an upper limit of 100 for the conviction rate and include 3 regional dummies. In regression (1) no explanatory variables are endogenous, in regression (2) prosecutorial budget and index crime are endogenous, and in regression (3) only budget is endogenous. Regression (2) uses Stata's twostep option. Robust standard errors are used in (1) and (3). See the text for discussion of the instruments and the two-step option.

Table 3 looks at how the number of prosecutions changes with the budget and other variables. Since this variable is not bounded as conviction rate is by the upper limit of $100 \%$, we use simple least squares instead of tobit. As in Table 2, no explanatory variables are endogenous in the first column, both budget and crime are instrumented 
in the second, and budget alone is instrumented in the third. Since these are least squares regressions rather than tobit, a Hausman specification test is appropriate instead of the Wald test. We find we cannot reject exogeneity of either or both crime and budget (the significance levels are .45 for budget, .50 for crime, and .50 for both). We will take column (1) as our preferred regression. Columns (1) and (3), however, have similar patterns of statistical significance, so whether or not we instrument for the budget makes little difference.

In Table 3, the prosecutor's budget does have a highly significant effect on the number of prosecutions, with an elasticity of $25 \%$. This regression holds constant the population, which naturally also has a positive effect. The amount of crime has an insignificant effect, conditioning on budget and population. Districts with more crime (but the same budget) do not seem to have more prosecutions.

Of the political variables, the chief prosecutor's salary and whether he is appointed have no effect on the number of prosecutions, but the longer he is in office, the fewer the prosecutions, an elasticity of $6.7 \%$ that is mrginally significant. Thus, this regression lends mild support to the Political Model.

Of the control variables, being more Republican or in a metropolitan area has no significant effect. The South and West prosecute more than the Northeast and Midwest. The percentage African American has a highly significant positive effect.

Conviction rates do rise with prosecution budgets and are higher where prosecutors are elected rather than appointed and where terms of office are shorter. The number of prosecutions also rises with the budget, but falls with the prosecutor's tenure in office. Overall, this lends mild support to the Political Model over the Social Planner Model. As predicted by both of the models, the conviction rate falls with the number of prosecutions, but it falls very slightly. 
Table 3: Explaining the Number of Prosecutions

(1) (2)

(3)

\begin{tabular}{|c|c|c|c|}
\hline Prosecutorial Budget (millions) & $\begin{array}{r}179.15^{* *} \\
(2.55) \\
\end{array}$ & $\begin{array}{r}-82.36 \\
(0.35)\end{array}$ & $\begin{array}{r}390.33^{*} \\
(1.70)\end{array}$ \\
\hline Chief Prosecutor's Salary (\$10,000’s) & $\begin{array}{r}-7.86 \\
(0.76)\end{array}$ & $\begin{array}{r}5.70 \\
(0.27)\end{array}$ & $\begin{array}{r}-10.77 \\
(0.96)\end{array}$ \\
\hline Chief Prosecutor Appointed (=1) & $\begin{array}{r}-570.46 \\
(1.25)\end{array}$ & $\begin{array}{r}439.21 \\
(0.39)\end{array}$ & $\begin{array}{r}-1263.96 \\
(1.34)\end{array}$ \\
\hline Years in Office & $\begin{array}{r}-4.29^{*} \\
(1.74)\end{array}$ & $\begin{array}{r}-4.58 \\
(1.62)\end{array}$ & $\begin{array}{r}-4.88^{*} \\
(1.74)\end{array}$ \\
\hline Term of Office & $\begin{array}{r}27.13 \\
(0.83)\end{array}$ & $\begin{array}{r}3.68 \\
(0.08)\end{array}$ & $\begin{array}{r}39.61 \\
(1.24)\end{array}$ \\
\hline Population (1000's) & $\begin{array}{r}5.59 * * * \\
(4.02)\end{array}$ & $\begin{array}{r}5 \\
(1.33)\end{array}$ & $\begin{array}{r}3.72^{* *} \\
(2.16)\end{array}$ \\
\hline Number of Index Crimes (1,000's) & $\begin{array}{r}69.47 \\
(0.46)\end{array}$ & $\begin{array}{r}548.75 \\
(0.77)\end{array}$ & $\begin{array}{r}-41.63 \\
(0.23)\end{array}$ \\
\hline African-American Population (\%) & $\begin{array}{r}18.75^{* * * *} \\
(5.41)\end{array}$ & $\begin{array}{r}14.20^{* *} \\
(2.42)\end{array}$ & $\begin{array}{r}20.74^{* * *} \\
(4.91)\end{array}$ \\
\hline Vote for Bush in $2000(\%)$ & $\begin{array}{r}2.65 \\
(1.18)\end{array}$ & $\begin{array}{r}0.34 \\
(0.09)\end{array}$ & $\begin{array}{r}4.18 \\
(1.28)\end{array}$ \\
\hline Metropolitan Area $(=1)$ & $\begin{array}{r}-68.39 \\
(0.89)\end{array}$ & $\begin{array}{r}-78.22 \\
(0.92)\end{array}$ & $\begin{array}{r}-35.65 \\
(0.49)\end{array}$ \\
\hline Constant & $\begin{array}{r}-192.92 \\
(1.05)\end{array}$ & $\begin{array}{r}10.9 \\
(0.03)\end{array}$ & $\begin{array}{r}-336.72 \\
(1.33)\end{array}$ \\
\hline
\end{tabular}

Notes: In parenthesis are z-statistics. *, **, and *** indicate significance at the $10 \%, 5 \%$, and 1\% levels. All regression use least squares and include 3 regional dummies, not reported. In regression (1) no explanatory variables are endogenous, in regression (2) prosecutorial budget and index crime are endogenous, and in regression (3) only budget is endogenous. Robust standard errors are used. See the text for discussion of the instruments.

The theoretical model established that the conviction rate might actually fall with the prosecutor's budget because the larger budget causes him to pursue more difficult cases. The conviction rate regressions in Table 2 would not detect this, because they condition on the number of cases prosecuted. If instead we simply look at the correlation between the conviction rate and the prosecutor's budget per capita, it is -.029, which is indeed negative, but tiny. Another approach is to see how the conviction rate 
depends on the budget when we condition on all of our explanatory variables except for budget. This can be done by repeating regression (3) of Table 2 but omitting cases prosecuted as an explanatory variable. The result is that the budget comes in in positive and significant, as before. That makes sense, since the effect of the number of prosecutions we found in regression (3) was tiny, an elasticity of $-3.1 \%$, so that if the elasticity of prosecutions with respect to budget is the $25 \%$ we found in Table 3 's regression (3), the negative indirect effect of more prosecutions is still less than the positive direct effect of the budget on the conviction rate. Thus, the theoretical possibility of the conviction rate falling with an increase in the prosecutor's budget is not an empirical actuality in our U.S. data.

\section{Conclusions}

A prosecutor's high conviction rate may not be a sign that he is tough on crime and doing a good job. Instead, he might just be taking easy cases and letting too many criminals go without prosecuting them. We have explored the implications of this idea for a theory of prosecutors and used it to think about prosecutions in Japan and the United States. Prosecutors have a choice between using extra resources to prosecute their current level of cases harder, the intensive margin, or to increase the prosecution rate, the extensive margin. A social planner would want both margins increased if the budget expands. Prosecutors are agents of the voters, however, which means they are subject to the temptation of agency slack and that they are monitored using imperfect summary statistics such as the conviction rate. As a result, we do not necessarily see increases in the budget spent on increasing the conviction rate, or even on increasing the prosecution rate. This may be particularly true for prosecutors who are elected, as in most of the United States, but appointed. Japanese prosecutors seem, with their low budget compared to American prosecutors, to have low prosecution rates and high conviction rates. We do find that higher budgets are associated with both higher amounts of prosecution and higher conviction rates conditioning on the amount of prosecution. We also find that appointed prosecutors in the United States do have lower conviction rates than elected ones and that those with longer tenure in office prosecute fewer cases. 


\section{References}

Adelstein, Richard. 1992a. "The Plea Bargain in Theory: A Behavioral Model of the Negotiated Guilty Plea," 44 Southern Economic Journal 488-503.

Adelstein, Richard. 1978b. "The Negotiated Guilty Plea: A Framework for Analysis," 53 New York University Law Review 783-834.

Albonetti, Celesta. 1986. "Criminality, Prosecutorial Screening,and Uncertainty: toward a Theory of Discretionary Decision Making in Felony Case Processings," 24 Criminology 623-644.

Baker, Scott and Claudio Mezzetti. 2001. "Prosecutorial Resources, Plea Bargaining, and the Decision To Go to Trial," 17 Journal of Law, Economics and Organization 149-167.

Boylan, Richard. 2004a. "Do the Sentencing Guidelines Influence the Retirement Decisions of Federal Judges?" 33 Journal of Legal Studies 231-253.

Boylan, Richard. 2004b. "Salaries, Turnover, and Performance in the Federal Criminal Justice System," 47 Journal of Law and Economics 75-92.

Boylan, Richard. 2005. "What Do Prosecutors Maximize? Evidence from the Careers of U.S. Attorneys," 7 American Law and Economics Review 379-402.

Butler, Paul. 1995. "Racially Based Jury Nullification: Black Power in the Criminal Justice System," 105 Yale Law Journal 677-725.

Cowling Allen. "Basic Criminal Procedure From Arrest Through Trial," http: //www.allencowling.com/false04B.htm.

DeFrances, Carol J. and Steadman, G.. 1998. "Prosecutors in State Courts, 1996," Washington, DC, U.S. Dept. of Justice, Office of Justice (July 1998).

DeFrances, Carol. 2001. "State Court Prosecutors in Large Districts, 2001," NCJ 191206 (December 2001).

DeFrances, Carol. 2002. "Prosecutors in State Courts, 2001, National Survey of Prosecutors," (NCJ-193441), http://www.ojp.usdoj.gov/bjs/abstract/psc01.htm (May 2002).

DeFrances, Carol. 2003. "State Court Prosecutors in Small Districts, 2001," U.S. Department of Justice, Bureau of Justice Statistics, NCJ 196020. http://www.ojp. usdoj.gov/bjs/abstract/scpsd01.htm (January 2003). 
Forst, Brian \& Kathleen Brosi. 1977. "A Theoretical and Empirical Analysis of the Prosecutor," 6 Journal of Legal Studies 177-191.

Glaeser, Edward, D. Kessler, and Ann Piehl. 2000. "What Do Prosecutors Maximize? An Analysis of the Federalization of Drug Crimes," 2 American Law and Economics Review 259-290.

Huber, Gregory and Sanford Gordon. 2002. "Information, Evaluation, and the Electoral Incentives of Criminal Prosecutors," 46 American Journal of Political Science 334-351.

Huber, Gregory and Sanford Gordon. 2004. "Accountability and Coercion: Is Justice Blind When It Runs for Office?," 48 American Journal of Political Science 247-263.

Huber, Gregory and Sanford Gordon. 2005. "Incumbent Incentives and the Informational Role of Challengers," Yale Political Science Working Paper (May 2005).

Johnson, David. 2001. The Japanese Way of Justice: Prosecuting Crime in Japan. Oxford: Oxford University Press.

Landes, William. 1971. "An Economic Analysis of the Courts," 14 Journal of Law and Economics 61-107.

Miceli, Thomas. 1996. "Plea Bargaining and Deterrence: An Institutional Approach," 3 European Journal of Law and Economics 249-264.

Miceli, Thomas. 1990. "Optimal Prosecution of Defendants Whose Guilt Is Uncertain," 6 Journal of Law, Economics, \&S Organization 189-201.

Misner, Robert. 1996. "Recasting Prosecutorial Discretion," 86 Journal of Criminal Law and Criminology 717-777.

Mott, Nicole. 2002. "Part II: The Role of Juries in State Courts," in Brian Ostrom, Neal B. Kauder, and Robert C. LaFountain, eds.Examining the Work of State Courts, 2001 (Williamsburg, VA: National Center for State Courts, 2002) http://www.ncsconline.org/d_research/ CSP/2001_Files/2001_Front_Matter.pdf.

Myers, Martha \& John Hagan. 1979. "Private and Public Trouble: Prosecutors and the Allocation of Court Resources," 26 Social Problems 439-451.

Posner, Richard. 1998. Economic Analysis of Law, 5th ed., Sec. 22.3, New York: Aspen.

Priest, George and Benjamin Klein. 1984. "The Selection of Disputes for Litigation," 13 Journal of Legal Studies 1-55. 
Rainville, Gerard. 2001. "An Analysis of Factors Related to Prosecutor Sentencing Preferences," 12 Criminal Justice Policy Review 295-310 (2001).

Ramseyer, J. Mark and Eric Rasmusen. 2001. "Why Is the Japanese Conviction Rate So High?" 30 Journal of Legal Studies 53-88.

Ramseyer, J. Mark and Eric Rasmusen. 2003. Measuring Judicial Independence: The Political Economy of Judging in Japan. Chicago: The University of Chicago Press.

Reinganum, Jennifer. 1988. "Plea Bargaining and Prosecutorial Discretion," 78 American Economic Review 713-728.

Reinganum, Jennifer. 1993. "The Law Enforcement Process and Criminal Choice," 13 International Review of Law and Economics 115-134.

Rhodes, William. 1976. "The Economics of Criminal Courts: A Theoretical and Empirical Investigation," 5 Journal of Legal Studies 311-340.

Saxonhouse, Gary. 2001. "How to Explain Japan's Legal System," 3 American Law and Economics Review 376-390.

Snyder, Edward. 1990. "The Effect of Higher Criminal Penalties on Antitrust Enforcement," 33 Journal of Law and Economics 439-462.

U.S. Census Bureau. The Statistical Abstract of the United States 2004-2005, http://www . census.gov/prod/2004pubs/04statab/law.pdf, 2005.

United Nations Office on Drugs and Crime. The Sixth United Nations Survey on Crime Trends and the Operation's of Criminal Justice Systems (1995 - 1997), http://www . unodc.org/unodc/en/ crime_cicp_survey_sixth.html?print=yes (June 2001).

U.S. Dept. of Justice, Bureau of Justice Statistics. National Prosecutors Survey [Census], 2001 [Computer file]. Conducted by the National Opinion Research Center. ICPSR ed. Ann Arbor, MI, Inter- university Consortium for Political and Social Research [producer and distributor], 2002.

U.S. Dept. of Justice, Bureau of Justice Statistics. Questionnaire, National Prosecutors'Survey [Census], 2001, http://www.ojp.usdoj.gov/bjs/pub/pdf/quest_archive/nsp01.pdf,2002.

U.S. Dept. of Justice, Bureau of Justice Statistics. "Felony Defendants in Large Urban Counties, 2002," http://www.ojp.usdoj.gov/bjs/pub/pdf/fdluc02.pdf 02/06 NCJ 210818.

U.S. Dept. of Justice, Federal Bureau of Investigation. Uniform Crime Reporting Program Data [United States], County-Level Detailed Arrest and Offense Data, 2001 [Computer file]. ICPSR ed. Ann Arbor, MI, Inter-university Consortium for Political and Social Research [producer and 
distributor], 2003. 